\title{
Front Matter: Volume 9115
}

, "Front Matter: Volume 9115," Proc. SPIE 9115, Energy Harvesting and Storage: Materials, Devices, and Applications V, 911501 (19 June 2014); doi: $10.1117 / 12.2074006$

SPIE Event: SPIE Sensing Technology + Applications, 2014, Baltimore, MD, United SPIE. States 


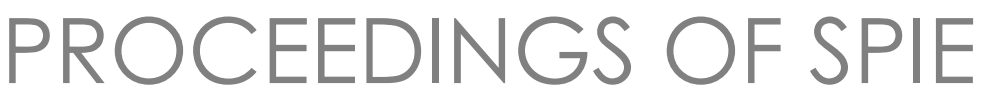

\title{
Energy Harvesting and Storage: Materials, Devices, and Applications V
}

\author{
Nibir K. Dhar \\ Palani Balaya \\ Achyut K. Dutta \\ Editors
}

5-6 May 2014

Baltimore, Maryland, United States

Sponsored and Published by

SPIE 
The papers included in this volume were part of the technical conference cited on the cover and title page. Papers were selected and subject to review by the editors and conference program committee. Some conference presentations may not be available for publication. The papers published in these proceedings reflect the work and thoughts of the authors and are published herein as submitted. The publisher is not responsible for the validity of the information or for any outcomes resulting from reliance thereon.

Please use the following format to cite material from this book:

Author(s), "Title of Paper," in Energy Harvesting and Storage: Materials, Devices, and Applications $V$, edited by Nibir K. Dhar, Palani Balaya, Achyut K. Dutta, Proceedings of SPIE Vol. 9115 (SPIE, Bellingham, WA, 2014) Article CID Number.

ISSN: 0277-786X

ISBN: 9781628410525

Published by

SPIE

P.O. Box 10, Bellingham, Washington 98227-0010 USA

Telephone +1 3606763290 (Pacific Time) · Fax +1 3606471445

SPIE.org

Copyright @ 2014, Society of Photo-Optical Instrumentation Engineers.

Copying of material in this book for internal or personal use, or for the internal or personal use of specific clients, beyond the fair use provisions granted by the U.S. Copyright Law is authorized by SPIE subject to payment of copying fees. The Transactional Reporting Service base fee for this volume is $\$ 18.00$ per article (or portion thereof), which should be paid directly to the Copyright Clearance Center (CCC), 222 Rosewood Drive, Danvers, MA 01923. Payment may also be made electronically through CCC Online at copyright.com. Other copying for republication, resale, advertising or promotion, or any form of systematic or multiple reproduction of any material in this book is prohibited except with permission in writing from the publisher. The CCC fee code is 0277-786X/14/\$18.00.

Printed in the United States of America.

Publication of record for individual papers is online in the SPIE Digital Library.

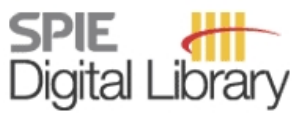

SPIEDigitalLibrary.org

Paper Numbering: Proceedings of SPIE follow an e-First publication model, with papers published first online and then in print and on CD-ROM. Papers are published as they are submitted and meet publication criteria. A unique, consistent, permanent citation identifier (CID) number is assigned to each article at the time of the first publication. Utilization of CIDs allows articles to be fully citable as soon as they are published online, and connects the same identifier to all online, print, and electronic versions of the publication. SPIE uses a six-digit CID article numbering system in which:

- The first four digits correspond to the SPIE volume number.

- The last two digits indicate publication order within the volume using a Base 36 numbering

system employing both numerals and letters. These two-number sets start with 00, 01, 02, 03, 04, $05,06,07$

$08,09,0 A, O B \ldots 0 Z$, followed by $10-1 Z, 20-2 Z$, etc.

The CID Number appears on each page of the manuscript. The complete citation is used on the first page, and an abbreviated version on subsequent pages. Numbers in the index correspond to the last two digits of the six-digit CID Number. 


\section{Contents}

vii Conference Committee

\section{SESSION 1 ENERGY HARVESTING AND RELATED TECHNOLOGIES}

911503 Development of irradiation methods and degradation modeling for state-of-the-art space solar cells (Invited Paper) [911 15-2]

T. Ohshima, S. Sato, Japan Atomic Energy Agency (Japan); T. Sumita, T. Nakamura, M. Imaizumi, Japan Aerospace Exploration Agency (Japan)

911504 Performance of tantalum-tungsten alloy selective emitters in thermophotovoltaic systems [9115-3]

V. Stelmakh, Massachusetts Institute of Technology (United States); V. Rinnerbaver, Johannes Kepler Univ. Linz (Austria); W. R. Chan, J. J. Senkevich, J. D. Joannopoulos, M. Soljačić, I. Celanovic, Massachusetts Institute of Technology (United States)

\section{SESSION 2 NOVEL ENERGY HARVESTER}

911507 High-efficiency energy harvesting using TAGS-85/half-Heusler thermoelectric devices (Invited Paper) [9115-6]

G. Bulman, B. Cook, RTI International (United States)

911508 MEMS electromagnetic energy harvesters with multiple resonances [9115-7] S. R. Nelatury, Penn State Erie, The Behrend College (United States); R. Gray, Penn State Harrisburg (United States)

911509 Piezoelectric-based event sensing and energy-harvesting power sources for thermal battery initiation in gun-fired munitions [9115-8]

J. Rastegar, D. Feng, Omnitek Partners, LLC (United States); C. Pereira, U.S. Army Armament Research, Development and Engineering Ctr. (United States)

\section{SESSION 3 ADVANCED HARVESTING DEVICE AND APPLICATIONS}

9115 OD Integrated soldier power and data system (ISPDS) [9115-12]

R. Ostroumov, T. Forrester, K. Lee, R. Stephens, A. Lai, M. Zahzah, Physical Optics Corp. (United States)

$91150 G$ Thermoelectric energy harvesting for a solid waste processing toilet [9115-39] C. D. Stokes, N. G. Baldasaro, G. E. Bulman, B. R. Stoner, RTI International (United States) 
91150 Electrodics: mesoscale physicochemical interactions in lithium-ion batteries (Invited Paper) [9115-16]

P. P. Mukherjee, C.-F. Chen, Texas A\&M Univ. (United States)

$91150 \mathrm{~J} \quad$ Tritium power source for long-lived sensors [9115-17]

M. S. Litz, D. C. Katsis, J. A. Russo, J. J. Carroll, U.S. Army Research Lab. (United States)

9115 OK On the coupling between stress and voltage in lithium-ion pouch cells (Invited Paper)

[9115-18]

J. Cannarella, C. Z. Leng, C. B. Arnold, Princeton Univ. (United States)

$9115 \mathrm{OL}$ Patternable gel electrolyte infiltrated into all-solid porous Li-ion electrodes (Invited Paper) [9115-19]

K. Sun, S. J. Dillon, Univ. of Illinois at Urbana-Champaign (United States)

\section{SESSION 5 ADVANCED STORAGES: BATTERIES AND CAPACITORS}

$911500 \quad$ Nanostructured metal-oxides for use as high power and energy density storage electrodes [9115-23]

G. C. Mondragón-Rodríguez, B. Saruhan, Deutsches Zentrum für Luft- und Raumfahrt e.V. (Germany)

\section{POSTER SESSION}

9115 OP Modeling of high-efficiency ITO/ZnO quantum wire photovoltaic [91 15-28] F. Althowibi, E. Donkor, Univ. of Connecticut (United States)

$91150 Q \quad J u n c t i o n l e s s ~ t h i n-f i l m$ ferroelectric oxides for photovoltaic energy production [91 15-27] F. K. Rezaie, D. Panjwani, J. Nath, C. J. Fredricksen, Univ. of Central Florida (United States); I. O. Oladeji, SISOM Thin Films, LLC (United States); R. E. Peale, Univ. of Central Florida (United States)

9115 OR Analysis of solar cell using the Lambert W function with Maple [9115-24] D. Villegas, Univ. EAFIT (Colombia)

9115 OS Single stage AC-DC converter for Galfenol-based micro-power energy harvesters [91 15-26]

P. Cavaroc, C. Curtis, Space and Naval Warfare Systems Ctr. Atlantic (United States); S. Naik, Space and Naval Warfare Systems Command (United States); J. Cooper, Middle Tennessee State Univ. (United States)

9115 OV Procedure to determine module distribution within a solar array to increase the net energy collection in a solar competition vehicle [9115-31]

N. Suárez-Castañeda, A. Gil-Herrera, J. Barrera-Velásquez, G. Osorio-Gómez,

R. Mejía-Gutiérrez, Univ. EAFIT (Colombia) 
9115 OW Designing a concentrating photovoltaic (CPV) system in adjunct with a silicon photovoltaic panel for a solar competition car [9115-29]

A. Arias-Rosales, J. Barrera-Velásquez, G. Osorio-Gómez, R. Mejía-Gutiérrez, Univ. EAFIT (Colombia)

$91150 \mathrm{X}$ Can seismic (destructive) energy be stored after conversion into useful electrical or acoustic energy? [9115-30]

U. P. Verma, M. N. Sinha, Patna Science College (India)

9115 OY Pulse wireless photonic power transfer at high irradiance [9115-34]

H. S. Dhadwal, J. Rastegar, P. Kwok, Omnitek Partners, LLC (United States)

Author Index 
Proc. of SPIE Vol. $9115911501-6$

Downloaded From: https://www.spiedigitallibrary.org/conference-proceedings-of-spie on 26 Apr 2023 Terms of Use: https://www.spiedigitallibrary.org/terms-of-use 


\section{Conference Committee}

Symposium Chair

David A. Whelan, Boeing Defense, Space, and Security

(United States)

Symposium Co-chair

Wolfgang Schade, Technische Universität Clausthal (Germany) and Fraunhofer Heinrich-Hertz-Institut (Germany)

Conference Chairs

Nibir K. Dhar, Defense Advanced Research Projects Agency, Microelectronics Technology Office (United States)

Palani Balaya, National University of Singapore (Singapore)

Achyut K. Dutta, Banpil Photonics, Inc. (United States)

Conference Program Committee

Pulickel M. Ajayan, Rice University (United States)

Paul Boieriu, EPISOLAR, Inc. (United States)

Deryn Chu, U.S. Army Research Laboratory (United States)

M. Saif Islam, University of California, Davis (United States)

Nobuhiko P. Kobayashi, University of California, Santa Cruz

(United States)

Pooi See Lee, Nanyang Technological University (Singapore)

Pat McGrath, Booz Allen Hamilton Inc. (United States)

Robert Olah, Banpil Photonics, Inc. (United States)

Kimberly A. Sablon, U.S. Army Research Laboratory (United States)

A. Fred Semendy, U.S. Army Research Laboratory (United States)

Sivalingam Sivananthan, EPIR Technologies (United States)

Ashok K. Sood, Magnolia Optical Technologies, Inc. (United States)

Patrick J. Taylor, U.S. Army Research Laboratory (United States)

Sudhir B. Trivedi, Brimrose Corporation of America (United States)

Rama Venkatasubramanian, RTI International (United States)

Chunlei Wang, Florida International University (United States)

Priyalal Wijewarnasuriya, U.S. Army Research Laboratory

(United States) 


\section{Session Chairs}

1 Energy Harvesting and Related Technologies

Nibir K. Dhar, Defense Advanced Research Projects Agency (United States)

Achyut K. Dutta, Banpil Photonics, Inc. (United States)

2 Novel Energy Harvester

Roger E. Welser, Magnolia Solar, Inc. (United States)

Achyut K. Dutta, Banpil Photonics, Inc. (United States)

3 Advanced Harvesting Device and Applications

Gary E. Bulman, RTI International (United States)

Achyut K. Dutta, Banpil Photonics, Inc. (United States)

4 Advanced Batteries and Storage Devices

Palani Balaya, National University of Singapore (Singapore)

Jie Xiao, Pacific Northwest National Laboratory (United States)

5 Advanced Storages: Batteries and Capacitors

Shen J. Dillon, University of Illinois at Urbana-Champaign (United States)

Palani Balaya, National University of Singapore (Singapore) 